\title{
A 21st Century Approach in Analysing Health Precautions in London with Machine Learning Driven Data Mining
}

\author{
Özerk Yavuz ${ }^{1 *}$, \\ 1* Haliç University, Faculty of Management, Departmant of Management Information Systems, İstanbul, Turkey, (ORCID: 0000-0002-1371-688X), \\ ozerkyavuz@halic.edu.tr;ozerk@alumni.bilkent.edu.tr;dr.ozerk@gmail.com
}

(International Conference on Design, Research and Development (RDCONF) 2021 - 15-18 December 2021)

(DOI: 10.31590 /ejosat.1039544)

ATIF/REFERENCE: Yavuz, Ö. (2021). A 21st Century Approach in Analysing Health Precautions in London with Machine Learning Driven Data Mining. European Journal of Science and Technology, (32), 101-106.

\begin{abstract}
As in the past, today preventive treatments and health policies constitute an important role in combatting with several diseases, medical phenomenon like pandemies or epidemies. These approaches can prevent several health focused negative consequences in early stages or can give leaders and medical professionals advantage in managing risks associated with health concerns. Usually effective usage of early warning systems, analysis of historical data for exploratory and confirmatory understanding may provide several advantages in this context. In this study a historical data analysis has been applied to understand similar phenomena with the help of machine learning driven data mining. Clustering and classification performances and rules generated by these approaches have also been assessed.
\end{abstract}

Keywords: Health Restriction, Health Precaution, Covid-19, Pandemy, Epidemy, Clustering, Classification, Data Mining, Machine Learning, Quantitative Analysis, Supervised Learning, Unsupervised Learning

\section{Londra'daki Sağlık Önlemlerini Makine Öğrenimi Odaklı Veri Madenciliği Yöntemleri ile Analiz Etmede Bir 21. Yüzyıl Yaklaşımı}

Öz

Geçmişte olduğu gibi günümüzde de koruyucu tedaviler ve sağlık politikaları birçok hastalık, pandemi, salgın gibi tıbbi olgularla mücadelede önemli rol oynamaktadır. Bu tarz yaklaşımlar, sağlık odaklı bazı olumsuz sonuçları erken aşamalarda önleyebilmekte ve liderlere, tıp uzmanlarına sağlık sorunlarıyla ilişkili riskleri yönetmede avantaj sağlayabilmektedir. Genellikle erken uyarı sistemlerinin etkin kullanımı, keşifsel ve doğrulayıcı anlayış için geçmiş verilerin analizi bu bağlamda çeşitli avantajlar sağlayabilir. Bu çalışmada, makine öğrenmesine dayalı veri madenciliği yardımıyla benzer olguları anlamak için tarihsel bir veri analizi uygulanmıştır. Bu yaklaşımlar kapsamında kümeleme ve sınıflandırma teknikleri ile algoritma performansları ve kuralları değerlendirilmiştir.

Anahtar Kelimeler: Sağlık Kısıtlamaları, Sağlık Önlemleri, Covid-19, Pandemi, Salgın, Kümeleme, Sınıflandırma, Veri Madenciliği, Makine Öğrenimi, Kantitatif Analiz, Denetimli Öğrenme, Denetimsiz Öğrenme

\footnotetext{
* Corresponding Author: Asst. Prof. Dr. Özerk Yavuz, Haliç University, İstanbul, Turkey, ORCID: 0000-0002-1371-688X, ozerkyavuz@halic.edu.tr, ozerk@alumni.bilkent.edu.tr, dr.ozerk@gmail.com
} 


\section{Introduction}

As in the past, today preventive treatments, medical approaches and health policies constitute an important role in combatting with several diseases, medical phenomenon like pandemies or epidemies. These approaches can prevent several health related negative consequences in early stages or can give leaders and medical professionals advantage in managing risks associated with health concerns. Usually effective usage of early warning systems, analysis of historical data for exploratory and confirmatory understanding may provide several advantages in this context. In this study a historical data analysis has been applied to understand this phenomena in the city of London with the help of machine learning driven data mining.

It is a common practice to engage in legislative activities, prepare and enforce rules and regulations for a more sustainable, regulated and peacefull society, to prevent negative foreseen consequences assess and manage the risk associated to different phenomena in many contexts. Health associated rules, regulations, action plans in this scope are not much different. However in engaging and enforcing these regulatory activities, internationally consensed and agreed norms, which conforms with the expectations of the stakeholders of the society concerned, while preserving the rights and freedoms of individuals. These regulatory activities should also consider the findings of scientific researches, opinion leaders with their referral and expert power in these areas and society's needs and expectations. Strengths, weaknesses, opportunities, threats and consequences associated with these activities should always be assased and managed [5, 7]. Related preparation for different scenarious should be considered with several test cases and contingency plans. Dedication of necessary resources, training of the personel, creating action points and assigning the qualified trained personal to maintain these activities can be beneficial in many contexts. A good strategic perspective with right mission, vision and objectives that are fed with scientific and expert knowledge would ease the process of right target setting and a more organized, planned, leaded, controlled process in all levels including the operational level. Feedbacks and knowledge sharing between different levels in achieving these targets should also be facilitated with alignment meetings and with the help of different communication methods and methodologies [48, 49, 50].

As seen in literature, today by applying right analysis approaches and practices several insights and knowledge patterns can be discovered which can be used for better risk management and disease prevention processes and policies [25, 30, 57]. With the help of the decision support feature of these approaches provide, more efficient and effective policies can be maintained for a more sustainable environment and society. When root causes of pandemies, their antecedents and ways to combat in these settings indicated in literature, It is seen that applying right policies, preventive measures and risk management policies can give several advantages in many contexts in preventing the spread of the pandemics, lowering the work load of health system and personnel [1]. As seen in many systematical approaches for a smooth service responding to all service requests, as the input or workload increases, the processing unit should also be upgraded or enhanced similar to that in computerized systems, which means training and hiring more qualified health proffesionals for these scenarious in parallel to the pandemics or population growth. Expecting unrealistic performances for massive unrealistic workloads is not so much different than modern day slavery which omits human limits and human factor which was coined and is highly debated in various settings of scientific and business community [37, 38, 39, 46, 47]. Therefore smart, measurable, achievable, result oriented, targeted, realistic approaches and key performance indicators should be implemented while preserving the work life balance as seen in more civilized and modern societies. In this context conforming international norms, standards, expectations of the workers and society at large constitutes an important value for associated process implementations, change management and sustainability. [37, 38, $39,40,41,54,55,56]$. This may be beneficial for the creation of a nice organizational equity and reputation in many contexts regardless of organizational size or focus [42, 43]. On the other hand a more health consious society complying with the suggested precautions such as wearing masks, paying attention to hygenie and distance rules, vaccination for preventing the spread of pandemics would make a positive contribution in controlling the pandemics and activities of health system and proffesionals $[44,45]$

As indicated in various information sources and literature a significant contribution of these actions seem to make a positive impact on preventing or limiting negative consequences such as spreading the virus or bacteria caused pandemies or epidemies $[44,45]$. As in Covid-19 pandemics, in preventing virus caused pandemies some precautions, preventive measures and action points can be helpfull. Today it is seen that paying attention to hygenic rules, using masks to provide a barrier for the transmission of bodily fluids (oral, nasal), bacteria and viruses $[44,45]$. Applying distance rules, isolation can give many benefits in many aspects $[44,45]$. Also as seen in literature vaccination plans, programs, enhancing awareness on the benefits of preventive measures, utilizing conventional media or social media for forming a public opinion and public perception based on the scientificly proven, justified, accredited expert knowledge and studies may give several benefits in controlling the pandemies and associated health risks. Sharing of the results of proven and rejected hypothesis with conducted studies may provide an atmosphere and medium for further development of scientific body of knowledge and scientific communities contributions to a more sustainable society and environment at large. Based on the analysis results some hypothesis tests can generate results in parallel to the expectations of the common wisdom, experts, leaders, medical professionals and literature on the other hand some can generate more surprising results and insights for several types of vacummed or unvacummed empirical studies. A cumulative knowledge, statistically and scientifically justified and proven in this context may provide several advantages ,insights and be a good decision support point in applying more effective policies and actions in preventing health associated concerns and risks in similar phenomena. In this setting a holistic and integrated approach with opinion leaders with their referral and expert power in their areas of expertise, with associated findings discovered with scientific research methodologies would be beneficial.

If the history of bacteria or virus caused pandemies is investigated, it is seen that various precautions have took place in various settings for different cases in the leaders and policy makers of that time. Therefore lessons learned from previous experiences and studies can shed light for todays approaches as well. Covid-19 virus is a type of virus which can be transmitted from human to human in various settings and conditions. It may provide several negative consequences, health risks even death in 
some cases. Therefore applying preventions can give several advantages in preventing or controlling coronavirus caused diseases and its spread.

Starting from 2019, a coronavirus caused pandemy has been seen all over the world. As a result there has been a drastical change in the way of human's daily lives and their behavioral patterns. Coronavirus is a type of virus with its hazarding effects and influences. It has symptoms that are ranging from mild to severe. Several researches are being conducted for developing vaccines and medicines for preventing and treatment of coronavirus caused anomalies [58].

As the human nature suggests, human beings are in a tendency to minimize risks, maximize rewards, maximize their freedoms and engage in behavioral patterns that are likely and perceived as rewarding $[51,52]$. But a medical opinion leader or scientific study driven shaped policies, rules and regulations while preserving the freedoms of the society would provide more benefits while limiting the unwanted negative consequences that are foreseen. Therefore as seen in many areas in life and for living in a good, sustainable society similar rule, regulation, policy and reform approaches are needed to be expected and maintained in the health related causes and needs. In doing so qualitative and quantitatively driven aristhotle logic based studies may provide many insights. In this study clustering and classification algorithms of machine learning approaches in data mining has been applied as suggested in literature for making a contribution to the scientific body of knowledge and science community [25, $30,57]$. It can also provide a complimentary perspective in understanding the phenomena with its managerial implications to governmental leaders, business leaders and the society at large

\section{Material and Method}

\subsection{Researh Method}

In the research part an initial literature review has been conducted. This is later followed with developing a quantitative research methodology $[9,10,11,12,13]$. As Özerk asserts, DM (Data Mining) process can be applied for exploratory or confirmatory understanding of the phenomenon using primary or secondary data sources to discover meaningfull knowledge patterns. Unsupervised or supervised machine learning can be considered for several purposes as knowledge discovery, prediction or forecasting. It may provide an in-depth understanding of the topic of interest for the individuals, researchers, leaders, managers and stakeholders involved. [25, 30]. Data mining is mostly used with the aim of knowledge and insight discovery and prediction from quantitative and measurable data. Data mining process is composed of some set of structured steps. These steps include understanding and analysis of the situation and business problem which is later followed with the examination and pre-processing of data. Later a conceptual framework or model is built following the literature review and analysis approaches. Following the model development, testing of the model with supervised and unsupervised versions of machine learning approaches takes place. In the last stage predicted analysis results are assesed [14,15,16,17,18,19].

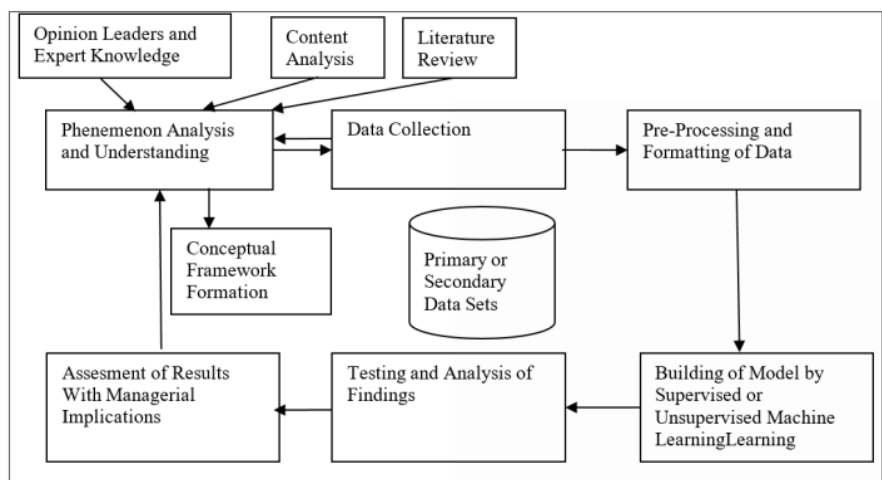

Figure 1. Data Mining Process Loop (Prepared by the Researcher)

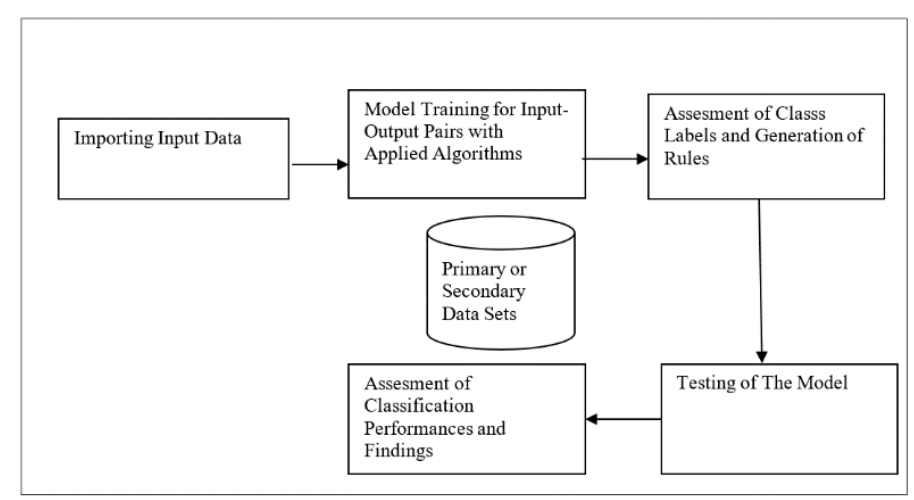

Figure 2. Supervised Machine Learning Algorithm Flow Composed of Model Building and Testing (Prepared by the Researcher)

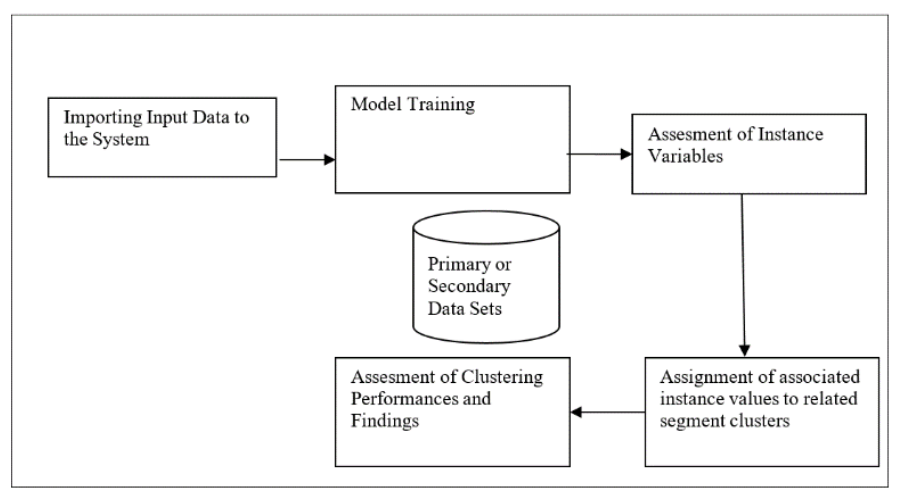

Figure 3. Unsupervised Machine Learning Algorithm Flow Composed of Model Building and Testing (Prepared by the Researcher)

For data set, public secondary data published online has been used composed of 26 instances and 12 attribues for the understanding of covid restrictions in city of London. Following the literature review of the study, a research model composed of variables Date, Quarter, Schools Closed Indicator, Pubs Closed Indicator, Shops Closed Indicator, Eating Places Closed Indicator, Stay at Home Status Indicator, Household Mixing Indoors Banned Indicator, Rule of 6 Status Indicator, Curfew Status Indicator, Eat Out To Help Out Indicator comosed. 
Table 1. List of Attributes

\begin{tabular}{|l|l|}
\hline Restriction & Nominal \\
\hline Date & Nominal \\
\hline Quarter & Nominal \\
\hline Schools Closed Indicator & Nominal \\
\hline Pubs Closed Indicator & Numeric \\
\hline Shops Closed Indicator & Numeric \\
\hline $\begin{array}{l}\text { Eating Places Closed } \\
\text { Indicator }\end{array}$ & Numeric \\
\hline Stay at Home Status Indicator & Numeric \\
\hline $\begin{array}{l}\text { Household Mixing Indoors } \\
\text { Banned Indicator }\end{array}$ & Numeric \\
\hline Rule of 6 Status Indicator & Numeric \\
\hline Curfew Status Indicator & Numeric \\
\hline Eat Out To Help Out Indicator & Numeric \\
\hline
\end{tabular}

\section{Findings}

As put forth by Özerk in his notable work, today many data mining processes apply a technical approach where independent or multivariate indicators and variables with the help of mapping functions are assigned to output class labels. In this process rules that would enhance the exploratory and confirmatory understanding of the phenameno is generated [25, 30, 57]. In this way data mining research methodology can be applied and considered in many disciplines as finance, medical, operations research, information technology, marketing, public relations, political science and sociology focused studies with its quantitative Aristotle logic [25, 30, 35, 57]. For the examination of the data set, supervised and unsupervised machine learning algorithms have been used. As indicated in literature machine learning is a form of data mining where models are developed and trained from data. In supervised learning, learning is formed from a training set of instances, which base on input and output pairs which are called attributes and class labels. In unsupervised learning system is fed by input however there is no output class labels used in training [19,20,21,22,23,24,25]. Among several machine learning approaches classification is a supervised machine learning method which base on a previously labeled set of instances used for training. Later based on the prior trainings the model learns to classify the new instances. On the other hand, clustering is an unsupervised method which aims to group different objects into groups of similar objects. In a cluster driven machine learning algorithm a cluster segment is composed of several variable values unique to that segment whereas is distinctive with its associated values from other segment variable values and objects [19, 24, 25, 26, 27].

Table 1. Assesment of Performance Indicators

\begin{tabular}{|l|r|r|r|r|r|r|}
\hline Method & \multicolumn{1}{|l|}{$\mathbf{J 4 8}$} & JRip & Part & $\begin{array}{l}\text { OneR } \\
\text { Metho } \\
\text { d }\end{array}$ & $\begin{array}{l}\text { Multilayer } \\
\text { Perceptro } \\
\text { n }\end{array}$ & $\begin{array}{l}\text { Bayesian } \\
\text { Network } \\
\text { s }\end{array}$ \\
\hline RMSE & 0,49 & 0,49 & 0.52 & 0.70 & $\mathbf{0 . 4 3}$ & 0.45 \\
\hline Precision & None & None & None & None & $\mathbf{0 , 7 1}$ & None \\
\hline $\begin{array}{l}\text { Correctly } \\
\text { Classified }\end{array}$ & 11.1 & 11.1 & 11,1 & 0 & $\mathbf{4 4 , 4 4}$ & 22,22 \\
$\%$ & 1 & 1 & 1 & & & \\
\hline $\begin{array}{l}\text { Incorrectl } \\
\text { y } \\
\text { Classified } \\
\%\end{array}$ & 88,8 & 88,8 & 88,8 & 100,00 & $\mathbf{5 5 , 5 6}$ & 77,78 \\
\hline
\end{tabular}

Performance indicators of applied data mining approaches have been analysed in these experiments. Rules predicted and generated by classification and clustering algorithms are listed. By applying the mentioned algorithms above with $2 / 3$ of the data set model built. Built model later tested with test cases prepared from the data set. In assessing the performances of the algorithms, some of the performance indicators in data mining have been considered. From these indicators the root mean square error, refers to the quantification of the average dispersion of a set of observations from a known value [28, 30] whereas precision indicates the proportion of predicted positive values that are correctly real positives in other words proportion of relevant instances among all retrieved instances [25, 29, 30]. Analysis revealed the performance indicators and rules as in Table 2 and Table 3 .

Table 4. Discovered Rules and Findings by Machine Learning

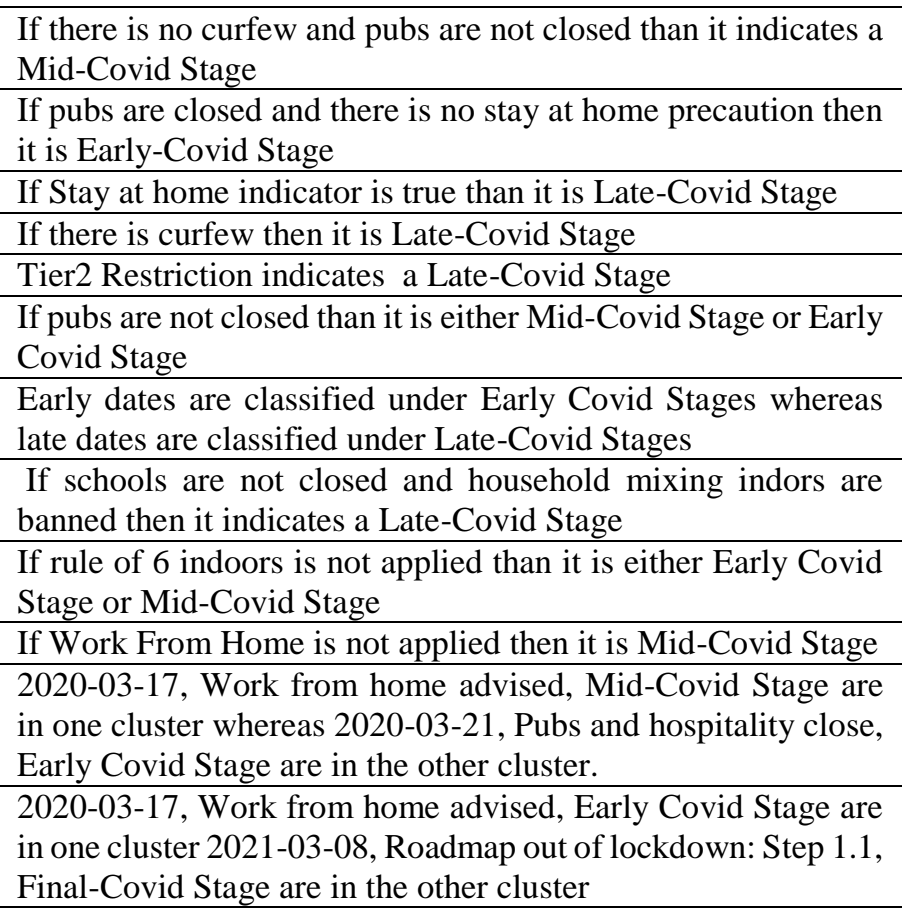

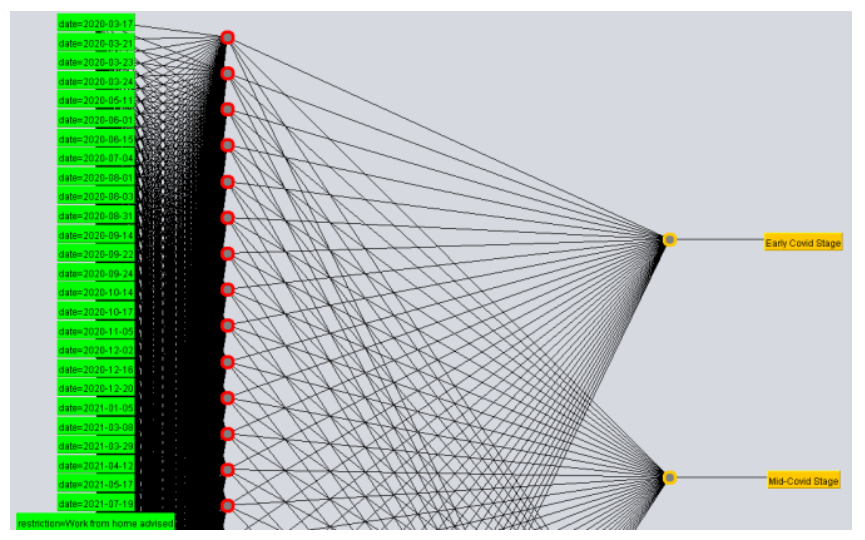

Figure 4. A section view of Neural Network Analysis conducted (Multi-Layer Perceptron)

\section{Conclusions and Recommendations}

As in the past, today preventive treatments, medical approaches and health policies constitute an important role in combatting with several diseases, medical phenomenon like 
pandemies or epidemies. These approaches can prevent several health related negative consequences in early stages or can give leaders and medical professionals advantage in managing risks associated with health concerns. Usually effective usage of early warning systems, analysis of historical data for exploratory and confirmatory understanding may provide several advantages in this context. In this study a historical data analysis has been applied to understand this phenomena in the city of London with the help of machine learning driven data mining for the coronavirus caused pandemy which started in 2019 .

It is a common practice to engage in legislative activities, prepare and enforce rules and regulations for a more sustainable, regulated and peacefull society, to prevent negative foreseen consequences assess and manage the risk associated to different phenomena in many contexts. Health associated rules, regulations, action plans in this scope are not much different. However in forming these rules, regulations, legislations expectations and freedom of individuals and society at large should be considered, strengthened by expert knowledge of opion leaders of the respective areas with findings of aristhole logic rooted scientific studies.

Some of the findings and rules discovered with unsupervised and supervised machine learning methodologies are as follow. If there is no curfew and pubs are not closed than it indicates a MidCovid Stage. If pubs are closed and there is no stay at home precaution then it is Early-Covid Stage. If Stay at home indicator is true than it is Late-Covid Stage. If there is curfew then it is LateCovid Stage. Tier2 Restriction indicates a Late-Covid Stage. If pubs are not closed than it is either Mid-Covid Stage or Early Covid Stage. Early dates are classified under Early Covid Stages whereas late dates are classified under Late-Covid Stages. If schools are not closed and household mixing indors are banned then it indicates a Late-Covid Stage. If rule of 6 indoors is not applied than it is either Early Covid Stage or Mid-Covid Stage. If Work From Home is not applied then it is Mid-Covid Stage. 202003-17, Work from home advised, Mid-Covid Stage are in one cluster whereas 2020-03-21, Pubs and hospitality close, Early Covid Stage are in the other cluster. 2020-03-17, Work from home advised, Early Covid Stage are in one cluster 2021-03-08, Roadmap out of lockdown: Step 1.1, Final-Covid Stage are in the other cluster. Also data mining analysis revealed that Multiplayer perceptron has been the top scorer among other algorithms that have been used in supervised machine learning approaches. It had the 44,44 percentage of correct classification rate, with 0,43 root mean square error and 0,71 precision.

To sum up, in this study clustering and classification algorithms of machine learning approaches in data mining has been applied as suggested in literature for making a contribution to the scientific body of knowledge and science community [25, $30,57]$. It can also provide a complimentary perspective in understanding the phenomena with its managerial implications to governmental leaders, business leaders and the society at large. Also various versions of emprical studies of this type, employing data mining methodologies alike can be considered in different settings, for similar scenarious and problem domains in exploratory and confirmatory understanding for future researchers of the topic.

\section{References}

[1] https://www.health.harvard.edu/diseases-andconditions/preventing-the-spread-of-the-coronavirus

e-ISSN: 2148-2683
[2] https://medical.mit.edu/covid-19-updates

[3] https://www.health.harvard.edu/diseases-andconditions/coronavirus-resource-center

[4] SWOT Analysis: Discover New Opportunities, Manage and Eliminate Threats". www.mindtools.com. 2016. Retrieved 24 February 2018.

[5] https://en.wikipedia.org/wiki/SWOT_analysis\#cite_note-1

[6] https://dictionary.cambridge.org/dictionary/english/

[7] Sammut-Bonnici, Tanya \& Galea, David. (2015). SWOT Analysis. 10.1002/9781118785317.weom120103.

[8] Satoshi Nakamoto, Bitcoin: A Peer-to-Peer Electronic Cash System,2008

[9] Águila, R.D.M., Ramírez, G.A., 2013. Series: basic statistics for busy clinicians. Allergol Immunopathol. 42 (5), pp. 485492.

[10] Blackmore, K., Bossomaier, T., 2002. Comparison of See5 and J48.PART algorithms for missing persons profiling. International Conference on Information Technology and Applications

[11] Frank E. and Witten I.H. (1998). Generating Accurate Rule Sets Without Global Optimization. In Shavlik, J., ed., Machine Learning: Proceedings of the Fifteenth International Conference, Morgan Kaufmann Publishers.

[12] Frank E. and Witten I.H. (2000). Data Mining: Practical Machine Learning Tools and Techniques with Java Implementations. Morgan Kaufmann Publishers: San Francisco, CA.

[13] Lemeshow S., Hosmer D.W., Klar J. \& Lwanga S.K., 1990. Adequacy of sample size in health studies. Chichester: John Wiley and Sons.

[14] Merriam-Webster, 2020. https://www. merriam-webster.com [date accessed 9 August 2020]

[15] Ramchoun, H. r., Idrissi, M. m., Ghanou, Y. y., \& Ettaouil, M. m. (2017). New Modeling of Multilayer Perceptron Architecture Optimization with Regularization: An Application to Pattern Classification. IAENG International Journal of Computer Science, 44(3), 261-269.

[16] Rosenblatt, F., \& Cornell Aeronautical Laboratory. (1958). The perceptron: A theory of statistical separability in cognitive systems (Project Para). Buffalo, N.Y: Cornell Aeronautical Laboratory.

[17] Shearer, C., 2000 The CRISP-DM model: the new blueprint for data mining. Journal of Data Warehousing, 5, 13-22.

[18] Simoudis, E. (1996). Reality Check for Data Mining. IEEE EXPERT, 11(5), pp.26-33

[19] Cohen, W. (1995). Fast effective rule induction. In A. Prieditis and S. Russell (eds.), Proceedings of the 12th International Conference on Machine Learning, Lake Tahoe, CA, pp.115-123.

[20] Saravanan, N., Gayathri V., 2018. Performance and classification evaluation of J48 algorithm and Kendall's based J48 algorithm (KNJ48). International Journal of Computer Trends and Technology

[21] Sasaki M., Kita K., 1998. Rule based text categorization using hierarchical categories, IEEE

[22] Surveymonkey, 2017. https://www.surveymonkey.com/mp/sample-size-calculator/ [date accessed 28 October 2017]

[23] Taniguchi M., Haft M., Hollm'en J., and Tresp V. (1998). Fraud detection in communications networks using neural and probabilistic methods. In Proceedings of the 1998 IEEE International Conference on Acoustics, Speech and Signal Processing (ICASSP'98), Volume II, pp. 1241-1244. 
[24] Venkatesan, E. V., 2015. Performance Analysis of Decision Tree Algorithms for Breast Cancer Classification. Indian Journal of Science and Technology.

[25] Yavuz Ö., 2019, A data mining approach for desire and intention to participate in virtual communities. International Journal of Electrical and Computer Engineering, 9(5).

[26] Ławrynowicz, A., Tresp, V., 2014. Introducing Machine Learning. Perspectives on Ontology Learning. AKA Heidelberg /IOS Press.

[27] Thomas, M., 2012. Root Mean Square Error Compared to, and Contrasted with, Standard Deviation. Surveying and Land Information Science, 72.

[28] Lawrynowicz, A., Tresp, V., 2014. Introducing Machine Learning. Perspectives on Ontology Learning. AKA Heidelberg /IOS Press.

[29] Thomas, M., 2012. Root Mean Square Error Compared to, and Contrasted with, Standard Deviation. Surveying and Land Information Science, 72.

[30] Karahoca D., Karahoca A., Yavuz Ö., 2013. An early warning system approach for the identification of currency crises with data mining techniques. Neural Computing and Applications, 23(7-8)

[31] Rasmussen, C. E.; Williams, C. K. I. Gaussian Processes for Machine Learning (Adaptive Computation and Machine Learning); The MIT Press: 2005.

[32] http://old.opentox.org/dev/documentation/components/gauss ianregressions

[33] https://en.wikipedia.org/wiki/Gaussian_process

[34] Anil Rajput, 2011 J48 and JRIP Rules for E-Governance Data, International Journal of Computer Science and Security (IJCSS), 5(2)

[35] https://plato.stanford.edu/entries/aristotle-logic/

[36] https://bezmialem.edu.tr/sks/tr/Sayfalar/HaberDetay.aspx?ne wsId=2441\&newsdetail=insanligi-etkileyen-bulasicihastaliklar-ve-pandemiler

[37] https://en.wikipedia.org/wiki/Slavery_in_the_21st_century

[38] https://carrcenter.hks.harvard.edu/pillars/modern-slavery

[39] https://cddrl.fsi.stanford.edu/humanrights/events/modern_da y_slavery_stratagies_and_solutions

[40] https://corporatefinanceinstitute.com/resources/knowledge/o ther/smart-goal/

[41] https://www.health.harvard.edu/blog/get-smart-about-yourgoals-this-strategy-can-help-you-stay-focused-and-on-trackat-any-age-

2017090112113\#: :text=A\%20good\%20way\%20to\%20esta blish,clearly\%20and\%20can\%20attain\%20them.\&text=Spec ific $\% 3 \mathrm{~A} \% 20 \mathrm{Goals} \% 20$ need $\% 20$ to $\% 20 \mathrm{be}$,connected $\% 20$ to $\% 20$ a $\% 20$ meaningful $\% 20$ outcome.

[42] https://hbr.org/2000/01/the-brand-report-card

[43] https://hbsp.harvard.edu/product/BEP224-PDF-ENG

[44] https://www.harvard.edu/coronavirus/

[45] https://www.health.harvard.edu/diseases-andconditions/preventing-the-spread-of-the-coronavirus

[46] https://en.wikipedia.org/wiki/Human_factors_and_ergonomi cs

[47] https://www.hse.gov.uk/humanfactors/introduction.htm

[48] Conkright, Todd. (2015). Using the Four Functions of Management for Sustainable Employee Engagement. Performance Improvement. 54. 10.1002/pfi.21506.

[49] https://www.aiuniv.edu/degrees/business/articles/functionsof-management

[50] https://hbr.org/2018/10/the-role-of-a-manager-has-tochange-in-5-key-ways
[51] Ajzen, I. \& Fishbein, M., 1980. Understanding attitudes and predicting social behaviour. Englewood Cliffs, NJ: Prentice Hall.

[52] Yavuz, Ö., 2018. Marketing Implications Of Participative Behavior In Virtual Communities, Bahcesehir University Graduate School of Social Sciences, Management-Marketing Program, Istanbul

[53] Yavuz, Ö., 2009. An early warning system approach for the identification of currency crises, Bahcesehir University Graduate School of Sciences, Computer Engineering Graduate Program, Istanbul

[54] https://sdp.cepr.harvard.edu/strategic-performanceindicators

[55] https://vdcscorecard.stanford.edu/key-performanceindicators

[56] https://hbr.org/2020/09/what-are-your-kpis-really-measuring

[57] Yavuz, Ö. (2021). A Public Perceptions Analysis With Data Mining Algorithms, 2. International "Başkent" Congress On Physical, Social and Health Sciences, Ankara

[58] Yavuz, Ö. (2021). A Data Mining Analysis of Coronavirus Cases and Vaccinations in The City of London. Astana, Ankara. 